\title{
PTPRE Gene Product
}

National Cancer Institute

\section{Source}

National Cancer Institute. PTPRE Gene Product. NCI Thesaurus. Code C106411.

A protein encoded by the PTPRE gene. 